\title{
Suppressive effect of dietary raffinose on T-helper 2 cell-mediated immunity
}

\author{
Taizo Nagura $^{1,2} *$, Satoshi Hachimura ${ }^{1}$, Masaaki Hashiguchi ${ }^{1}$, Yoshihiro Ueda ${ }^{1}$, Takashi Kanno ${ }^{2}$, \\ Hiroto Kikuchi $^{2}$, Kouji Sayama ${ }^{2}$ and Shuichi Kaminogawa ${ }^{1}$ \\ ${ }^{1}$ Department of Applied Biological Chemistry, The University of Tokyo, Bunkyo, Tokyo, Japan \\ ${ }^{2}$ Research Center, Nippon Beet Sugar Mfg. Co. Ltd, Obihiro, Hokkaido, Japan
}

(Received 21 June 2001 - Revised 18 April 2002 - Accepted 18 May 2002)

\begin{abstract}
The effects of the dietary oligosaccharide raffinose on immune responses, with special reference to its anti-allergic functions, were examined in vivo. First, feeding a diet supplemented with $50 \mathrm{~g}$ raffinose $/ \mathrm{kg}$ to BALB/c mice significantly $(P<0 \cdot 05)$ increased interleukin (IL) 12 secretion from isolated Peyer's patch (PP) cells in vitro compared with feeding control diet. When isolated PP cells were used as antigen-presenting cells (APC) for $\mathrm{CD}^{+}{ }^{+} \mathrm{T}$-splenocytes isolated from ovalbumin (OVA)-specific T-cell receptor transgenic (Tg) mice in the presence of OVA as antigen, significantly $(P<0.05)$ higher levels of interferon- $\gamma$ were observed in the cultures using APC from raffinose-fed mice than those cultures using APC from control mice. Second, the diet containing $50 \mathrm{~g}$ raffinose $/ \mathrm{kg}$ or control diet was fed to OVA Tg mice, and subsequently, OVA was added to each diet to prime $\mathrm{T}$ cells in vivo. $\mathrm{CD}^{+} \mathrm{T}$-cells from the mesenteric lymph nodes of the raffinose-fed mice secreted significantly $(P<0 \cdot 05)$ higher levels of IL-2 and significantly $(P<0.05)$ lower levels of IL-4 following in vitro antigenic stimulation compared with those of the control mice. These present results suggest that feeding raffinose may suppress differentiation of naïve T-helper (Th) cells into Th2 cells in the mesenteric lymphoid nodes. Last, feeding raffinose suppressed rises of serum immunoglobulin E levels in the Tg mice treated with long-term ingestion of OVA. In conclusion, it is suggested that dietary raffinose suppresses serum immunoglobulin E response through suppression of Th2-type immune response against oral antigen in the lymphoid organs located in or near the intestine.
\end{abstract}

Raffinose: Prebiotics: Immunity: Immunoglobulin E

Raffinose ( $\beta$-D-fructofuranosyl- $O-\alpha$-D-galactopyranosyl$(1,6)-\alpha$-D-glucopyranoside) is a non-digestible oligosaccharide that is distributed widely in the plant kingdom; for example sugar beet, sugar cane, cabbage, potato, grape, wheat, barley, maize and the seeds of many legumes (Rathbone, 1980). Thus, raffinose is an oligosaccharide ingested in a typical daily diet. In previous clinical studies, we have shown that the administration of raffinose to healthy volunteers resulted in a significant increase in faecal bifidobacteria and decrease of bacteroides and clostridia (Benno et al. 1987) and also a decrease of faecal putrefactive products such as $\mathrm{NH}_{3}, p$-cresol and indole (Fujisaki et al. 1994; Nagura et al. 1999). We have also shown that dietary raffinose improved the defecation frequency in human subjects (Nagura et al. 1999). These results show that raffinose has characteristics of prebiotics as well as other non-digestible oligosaccharides such as fructo-oligosaccharides (Hidaka et al. 1991) and galactooligosaccharides (Sako et al. 1999). Recently, we have reported that administration of raffinose improved atopic dermatitis in children (Matsuda et al. 1998). However, the mechanism by which raffinose improved this disease remains unclear.

Allergic diseases such as atopic dermatitis, allergic rhinitis and asthma are associated with specific immunoglobulin (Ig) E for antigens contained in foods and environmental substances. The production of $\mathrm{IgE}$ is regulated by T-helper (Th) cells, which have been classified into Th1 and Th2 subtypes. Naïve $\mathrm{CD}^{+}$T-cells can develop into Th1 cells in response to interleukin (IL) 12, whereas Th2 cells are dependent on IL-4 to differentiate (O'Garra, 1998). Th2 cells synthesize both IL-4, which

\footnotetext{
Abbreviations: APC, antigen-presenting cells; IFN, interferon; Ig, immunoglobulin; IL, interleukin; MLN, mesenteric lymph nodes; OVA, ovalbumin; PP, Peyer's patch; Tg, transgenic; Th, T-helper.

* Corresponding author: Dr Taizo Nagura, fax +81 15547 0711, email nagu@nitten.co.jp
} 
enhances $\operatorname{IgE}$ production by B cells through inducing $\operatorname{IgE}$ isotype class switching (Coffman et al. 1986), and IL-10, which down-regulates cytokine synthesis in Th1 cells (Sher \& Coffman, 1992; Fitch et al. 1993). Conversely, interferon (IFN)- $\gamma$ produced by Th1 cells enhances cellular immune responses, and preferentially inhibits proliferation of Th2 cells (Sher \& Coffman, 1992; Fitch et al. 1993). It is generally accepted that enhancement of Th2-mediated immunity cause IgE-dependent allergic diseases. Therefore, regulating the balance between Th1- and Th2-type immune responses to heterogeneous antigens properly is considered to be an important mechanism in the prevention and therapy of the diseases mentioned earlier.

The effect of raffinose of the improvement of atopic dermatitis led us to hypothesize that raffinose might inhibit $\mathrm{IgE}$ production through regulation of the balance between Th1- and Th2-type immune responses. However, at present little is known about the effect of prebiotics on immunomodulation (Sako et al. 1999; Van Loo et al. 1999). In the present study, we demonstrate for the first time that a dietary oligosaccharide, raffinose, suppressed IgE induced by orally fed antigen, probably through influencing the development of Th1 and Th2 cells in the lymphoid organs located in or near the intestine.

\section{Materials and methods}

\section{Animals}

BALB/c mice purchased from Japan Clea (Tokyo, Japan) were used for cytokine assays. Transgenic (Tg) mice from the colony maintained at in Hoshino Laboratory Animals (Saitama, Japan) were used randomly for antibody and cytokine assays. This $\mathrm{Tg}$ mouse expresses $\mathrm{T}$-cell receptor $\alpha \beta$ chain genes derived from a clone (7-3-7) of ovalbumin (OVA)-specific ${\mathrm{I}-\mathrm{A}^{\mathrm{d}}}$ restricted $\mathrm{CD}^{+}{ }^{+} \mathrm{Th}$ cells, and has a BALB/c genetic background (Sato et al.1994; Shida et al. 2000). The animals were housed in plastic cages (5-6 per cage for females, or 1 per cage for males) at $22 \pm 1{ }^{\circ} \mathrm{C}$ with a $12 \mathrm{~h}$ light-dark cycle and allowed free access to the basal or experimental diets and drinking water. All experiments were performed in accordance with the guideline for the care and use of laboratory animals of The University of Tokyo.

\section{Culture medium and antigen}

RPMI-1640 medium (Nissui Pharmaceutical Co., Tokyo, Japan) supplemented with heat-inactivated fetal calf serum $(100 \mathrm{ml} / \mathrm{l})$, penicillin $(100 \mathrm{U} / \mathrm{ml})$, streptomycin $(100 \mu \mathrm{g} / \mathrm{ml}), 5 \times 10^{-5} \mathrm{M}-2-$ mercaptoethanol and $2 \mathrm{mM}-\mathrm{L}-$ glutamine was used to culture lymphocytes. OVA of two grades were used as antigens. The first $(2 \times$ crystallized OVA; Seikagaku-kogyo, Tokyo, Japan) was used for the addition to the culture medium, and the second (albumin from eggs, containing $500 \mathrm{~g}$ OVA/kg; Wako Pure Chemical Industries, Osaka, Japan) for the addition to feed or drinking water.
Diets

The purified basal diet was composed of $(\mathrm{g} / \mathrm{kg})$ : casein 200.0, maize starch 481.7, $\alpha, \beta$-starch 90.0, sucrose 50.0, cellulose $50 \cdot 0$, soyabean oil $60 \cdot 0$, mineral mixture (AIN76) 50.0, vitamin mixture (AIN-76) 13.0, choline chloride 2.3, methionine 3.0 (American Institute of Nutrition, 1979). The OVA diet was prepared by adding OVA to the basal diet $(80 \mathrm{~g} / \mathrm{kg}$ diet $)$ instead of casein. The raffinose-containing diet and raffinose-OVA-containing diets were prepared by adding raffinose $(50 \mathrm{~g} / \mathrm{kg}$ diet $)$ to the diets instead of maize starch. The dose of raffinose included in the feed was based on the significant $(P<0.05)$ change in caecal microflora in rats when raffinose was given at $50 \mathrm{~g} / \mathrm{kg}$ ) (T Nagura, unpublished results). The diets were prepared in pellets and vacuum-sealed in plastic bags by Funabashi Farm (Chiba, Japan). Raffinose was used as raffinose pentahydrate (Nippon Beet Sugar Mfg. Co. Ltd, Tokyo, Japan), which was purified from sugar-beet molasses (Sayama et al. 1992), and whose purity measured by HPLC was $>995 \mathrm{~g} / \mathrm{kg}$ DM.

Production of cytokines in Peyer's patches from raffinose-
fed BALB/c mice

Female BALB/c mice (6-week-old) were randomly allocated to two groups ( $n 5$ per group) and each group was fed the basal diet (control group) or the raffinose-containing diet (raffinose group) for 2 weeks. Thereafter, the mice were killed, and PP cells were prepared individually from each mouse as a single-cell suspension by incubation with collagenase type-I ( $1 \mathrm{mg} / \mathrm{ml}$; Sigma, St Louis, MO, USA). Portions of these cell suspensions were stained with Trypan Blue and viable cells were counted. The PP cells $\left(2 \times 10^{6} / \mathrm{ml}\right)$ were cultured with or without $\mathrm{CD}^{+} \mathrm{T}$-cells $\left(5 \times 10^{5} / \mathrm{ml}\right)$, antigen $(1 \mathrm{mg} \mathrm{OVA} / \mathrm{ml})$ and oligosaccharides ( $1 \mathrm{mg}$ raffinose and $1 \mathrm{mg}$ melibiose $/ \mathrm{ml}$ ) in $1 \mathrm{ml}$ medium in a forty-eight well plate (Costar, Cambridge, MA, USA). The $\mathrm{CD}^{+}$T-cells were purified from splenocytes of $\mathrm{Tg}$ mice by means of magnetic cell sorting (Miltenyi Biotech $\mathrm{GmbH}$, Bergisch Gladbach, Germany) with anti-CD4 beads. The supernatant fractions were collected at $48 \mathrm{~h}$ for determination of cytokines.

\section{Effect of raffinose on production of cytokines in $C D 4^{+}$ T-cells from transgenic mice fed ovalbumin}

Female Tg mice (3-week-old) were randomly allocated to two groups ( $n 5$ per group). Each group was fed on the basal diet (control group) or the raffinose-containing diet (raffinose group) for 2 weeks. Each diet was then changed to the OVA diet or raffinose-OVA diet respectively and the mice maintained for 1 week. Thereafter, the mice were killed, and mesenteric lymph nodes (MLN) were harvested and pooled for each group, because it was experimentally difficult to prepare $\mathrm{CD}^{+}$T-cells from these organs and perform cultures individually for each mouse. MLN cells were prepared as a single-cell suspension by means of mechanical dissociation. Then, $\mathrm{CD}^{+} \mathrm{T}$-cells were purified from these pooled cells respectively by magnetic cell sorting with anti-CD4 beads. For determination 
of IL-2 levels in cultures, the CD4 ${ }^{+}$cells $\left(1 \times 10^{6} / \mathrm{ml}\right)$ were cultured with antigen-presenting cells (APC) $\left(4 \times 10^{6} / \mathrm{ml}\right)$ at various concentrations of OVA in $0.2 \mathrm{ml}$ medium in a ninety-six well flat-bottomed plate (Becton Dickinson Labware, Franklin Lakes, NJ, USA) for $36 \mathrm{~h}$. For determination of other cytokine levels, the $\mathrm{CD} 4^{+}$cells $\left(5 \times 10^{5} / \mathrm{ml}\right)$ were cultured with APC $\left(2 \times 10^{6} / \mathrm{ml}\right)$ at various concentrations of OVA in $1 \mathrm{ml}$ medium in forty-eight well plates (Costa) for $60 \mathrm{~h}$. APC were prepared from BALB/c mice splenocytes that incubated with mitomycin C $(50 \mu \mathrm{g} / \mathrm{ml}$, $45 \mathrm{~min}$ at $37^{\circ} \mathrm{C}$; Sigma). All cultures were performed in triplicate. Animal experiments were repeated six times.

\section{Effect of raffinose on antibody levels in the sera of transgenic mice fed ovalbumin orally}

$\mathrm{Tg}$ mice (4-week-old) were randomly allocated to two groups (four male, six female, total $n 10$ per group). Each group was fed the basal diet (control group) or the raffinose-containing diet (raffinose group). Two weeks after the start of experimental diets, the animals were exposed to OVA via the drinking water (20g OVA/l) until the end of the experiment. The antibody levels in the sera were determined by ELISA.

\section{ELISA for antibodies}

Determination of total and OVA-specific IgE levels was carried out by sandwich ELISA as previously described (Shida et al. 2000). Briefly, for determining total $\operatorname{IgE}$ levels, the wells of a ninety-six well immunoplate were coated with rat anti-mouse $\operatorname{IgE}$ monoclonal antibody. After blocking with bovine serum albumin, the test sample and standard mouse IgE were added. Subsequently, bound $\operatorname{IgE}$ was detected by sequential incubation with biotinylated rat anti-mouse IgE, streptavidin-alkaline phosphatase conjugate and enzyme substrate ( $p$-nitrophenylphosphate). For the assay of OVA-specific IgE, biotinylated OVA was used instead of biotinylated rat anti-mouse $\operatorname{IgE}$ as the second antibody. OVA-specific IgE titers were expressed as the relative value compared with hyperimmunized mouse serum. The hyperimmunized mouse serum was obtained from $\mathrm{Tg}$ mice sensitized by means of intraperitoneal administration of OVA adsorbed onto alum, and the OVA-specific IgE level of this control serum was arbitrarily taken to be 1000 units $/ \mathrm{ml}$.

The assay for OVA-specific IgG1 was performed by ELISA as previously described (Shida et al. 2000). OVA-specific IgG1 titers were expressed as the relative value as well as OVA-specific IgE.

\section{ELISA for cytokines}

IFN- $\gamma$, IL-2, IL-4 and IL-12 levels were determined by using a sandwich ELISA as previously described (Shida et al. 2000). Rat anti-mouse IFN- $\gamma$, IL-2, IL-4 and IL-12 (p40/p70) monoclonal antibodies were used as capture antibodies, with biotinylated rat anti-mouse IFN- $\gamma$ IL-2, IL-4 and IL-12 (p40/p70) respectively as the detection antibodies.

\section{Statistical analysis}

Results are expressed as mean values with their standard errors. Differences in antibodies levels in the sera of $\mathrm{Tg}$ mice and cytokines levels in BALB/c mice-PP cells cultures between experimental groups were analysed by using Student's $t$ test. Differences in cytokines levels from $\mathrm{CD}^{+}$MLN cells of Tg mice between experimental groups were analysed by using the Wilcoxon signedranks test with data obtained from six animal experiments.

\section{Results}

Feeding raffinose enhances interleukin 12 production from Peyer's patches antigen-presenting cells of BALB/c mice, which induces increased interferon- $\gamma$ production from $T$ cells

$\mathrm{BALB} / \mathrm{c}$ mice were fed the basal diet or raffinose-containing diet for 2 weeks and PP cells were then prepared from those mice. When the PP cells were cultured as APC with $\mathrm{CD}^{+}{ }^{+} \mathrm{T}$-cells from spleen of Tg mice and antigen, IFN- $\gamma$ production from $\mathrm{T}$ cells was induced (Fig. 1). Significantly $(P<0.05)$ higher production of IFN- $\gamma$ was induced in cultures stimulated by PP-APC from the raffinose group compared with cultures stimulated by PP-APC from the control group. IL-12 is a cytokine that enhances IFN- $\gamma$ production (O'Garra, 1998). We observed significantly $(P<0.05)$ higher levels of IL-12 in cultures with PP cells from raffinose-fed mice compared with cultures with PP cells from control mice (Fig. 1). This difference was observed even in the absence of $\mathrm{T}$ cells (Fig. 1). However, the addition of raffinose and melibiose in vitro resulted in no increase of IL-12 or IFN- $\gamma$ (Fig. 1).

\section{Feeding raffinose suppresses T-helper 2 cell cytokine production from $\mathrm{CD}^{+}$mesenteric lymph node cells of transgenic mice fed ovalbumin}

$\mathrm{Tg}$ mice were fed the OVA-free basal diet or raffinosecontaining diet for 2 weeks and were then maintained with OVA-containing experimental diets (OVA diet or raffinose-OVA diet) for 1 week. $\mathrm{CD}^{+}$MLN cells prepared from $\mathrm{Tg}$ mice of the raffinose group produced significantly $(P<0.05)$ higher levels of IL-2 and lower IL-4 levels in the cultures with APC at various concentrations of OVA than did those from the control group (Fig. 2). As regards IFN- $\gamma$, no difference between the groups was found.

\section{Feeding raffinose suppresses serum immunoglobulin E levels induced by oral ingestion of ovalbumin}

All Tg mice exposed to OVA orally showed a gradual increase of total and specific antibodies levels in the sera (Fig. 3). In the raffinose-treated group, a significantly $(P<0.05)$ lower concentration of total $\operatorname{IgE}$ in the sera was observed at week 8 compared with that in the control group. No significant differences were found for OVAspecific antibodies of $\operatorname{IgE}$ and $\operatorname{IgG} 1$ class between both groups, although the average titers of these specific antibodies in the raffinose group were lower than those in 

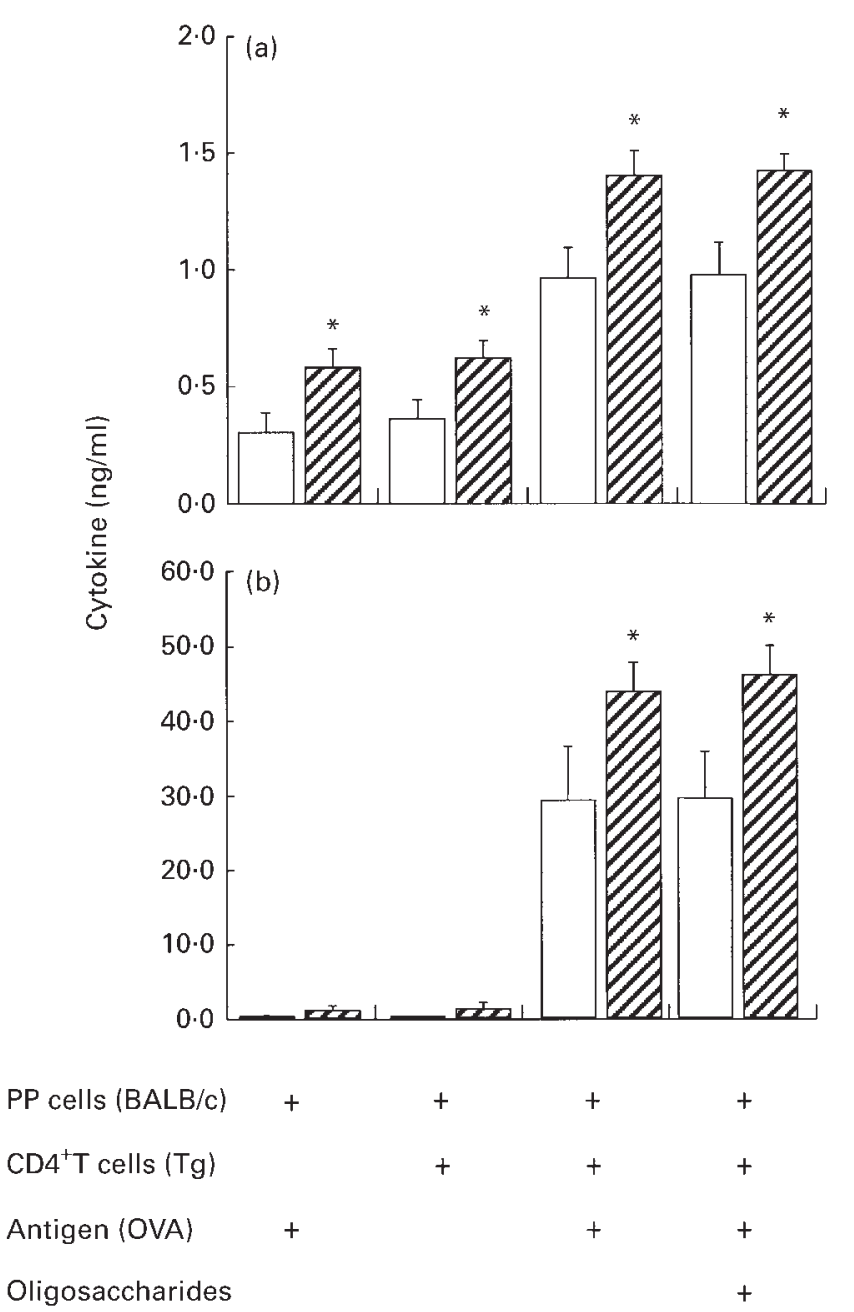

Treatment

Fig. 1. Effect of feeding raffinose on (a) interleukin (IL) 12 production from Peyer's patches (PP) cells of BALB/c mice, (b) interferon (IFN)- $\gamma$ production from $T$ cells. $\square$, Control; $\llbracket$, raffinose. PP cells from BALB/c mice fed a basal diet or raffinose-containing diet for 2 weeks were cultured with or without naïve CD4 ${ }^{+} \mathrm{T}$-cells, antigen (1 mg ovalbumin (OVA)/ml) and oligosaccharides (1 mg raffinose and $1 \mathrm{mg}$ melibiose $/ \mathrm{ml}$ ) for $48 \mathrm{~h}$. The levels of cytokines in the culture supernatant fractions were determined by ELISA. For details of diet and procedures, see p. 422. Values are means for five mice with standard errors shown by vertical bars. Mean values were significantly different from those of the control group: ${ }^{*} P<0.05$.

the control group. In the suppressive effect of raffinose on IgE response, there was no difference between male and female mice (results not shown).

\section{Discussion}

In the present paper, we showed that dietary raffinose suppressed the immune response related to type I allergy. First, we addressed PP, considered to be a secondary immune organ that absorbs foreign antigens such as food and microbes in the intestinal lumen, and induces the first immune response to these antigens. PP cells from raffinose-fed $\mathrm{BALB} / \mathrm{c}$ mice produced significantly $(P<0 \cdot 05)$ higher levels of IL-12 than those of the control group (Fig. 1). In addition, when the raffinose-group PP cells were cultured as APC with naïve $\mathrm{CD} 4^{+}$T-cells from OVA-specific T-cell receptor $\mathrm{Tg}$ mice in the presence of OVA as specific antigen, a significantly $(P<0.05)$ higher production of IFN- $\gamma$ was observed compared with control-group PP cells. Because IL-12-producing cells are considered capable of presenting antigens to $\mathrm{CD} 4^{+} \mathrm{T}$-cells, such as macrophages and dendritic cells (O'Garra, 1998), these results suggested that raffinose might influence APC in the PP, resulting in enhanced Th1-type immune responses against oral antigen mediated by IL-12 production.

Second, we showed that dietary raffinose decreased IL-4 levels from $\mathrm{CD}^{+}{ }^{+} \mathrm{T}$-cells of the MLN in OVA-specific $\mathrm{Tg}$ mice fed OVA (Fig. 2). In the present model, T cells are primed by orally ingested OVA. In addition to the decrease in IL-4 secretion from the MLN, it was observed that feeding raffinose increased IL-2 levels from $\mathrm{CD} 4^{+} \mathrm{T}$-cells of the MLN. Our present results suggest that dietary raffinose may suppress differentiation of naïve $\mathrm{CD}^{+}{ }^{+} \mathrm{T}$-cells into Th2 cells, because IL-2 is produced by naïve T-cells and Th1 cells, but not by Th2 cells, and IL-4 is derived from Th2 cells (Sher \& Coffman, 1992; Fitch et al. 1993). It is also possible that dietary raffinose reduced the ability of Th2 cells to secrete cytokines. The decrease of IL-4 levels may be associated with raffinose-induced enhancement of IL-12 production, because Th1 cells induced by IL-12 inhibit proliferation of Th2 cells (Sher \& Coffman, 1992; Fitch et al. 1993). On the other hand, with regard to IFN- $\gamma$, raffinose induced different responses in two experiments (Figs. 1 and 2), which might be due to differences between the experimental conditions. In Fig. 1, IFN$\gamma$ was produced by T cells that were primed in vitro for $2 \mathrm{~d}$ in the cultures with antigen and PP-APC from BALB/c mice fed raffinose, and in Fig. 2 it was produced by $\mathrm{T}$ cells that were primed in vivo by orally ingested antigen and had developed for $7 \mathrm{~d}$. Although at present the precise reason for the difference is unclear, it is clear that a shift in the balance of Th1 and Th2 was observed in both experiments.

Finally, we demonstrated that raffinose administration significantly suppressed serum total $\mathrm{IgE}$ levels in $\mathrm{Tg}$ mice in which a vigorous $\operatorname{IgE}$ response against orally administer OVA has been shown (Shida et al. 2000). We consider that total IgE in this Tg system contains IgE produced by non-specific B cells for OVA, as IL-4 secreted from OVA-specific $\mathrm{T}$ cells is able to promote development of Th2 cells and enhances IgE production from B cells, even if these cells have no specificity for OVA (Coffman et al. 1986; O'Garra, 1998). Our present results suggest that dietary raffinose suppresses total IgE response through decrease of IL-4 production by OVA-specific T-cells. In fact, dietary raffinose suppressed IL-4 production by $\mathrm{CD}^{+} \mathrm{T}$-cells from MLN in the Tg mice, which has been suggested to play a key role in the elicitation of a humoral response to orally administered antigen (Yamamoto et al. 2000).

Studies using germ-free animals have shown that colonization of microbes in the gut after birth is necessary for immunological development of the host (Berg, 1983; Sudo et al. 1997). In addition, specific strains of lactobacilli and bifidobacteria have been reported to enhance 

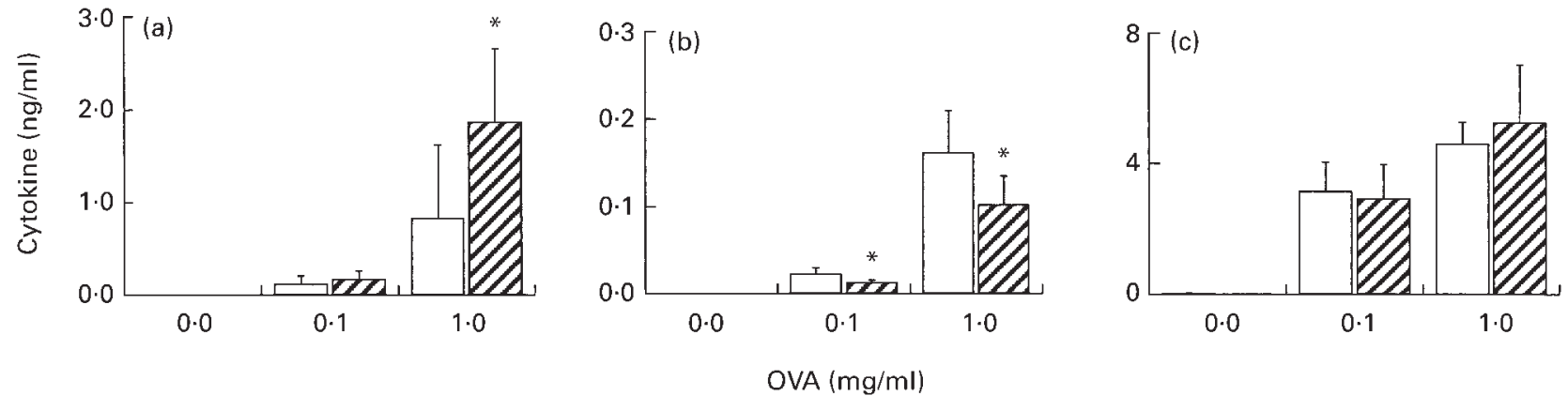

OVA (mg/ml)

Fig. 2. Effect of feeding raffinose on cytokine production from $C D 4^{+}$mesenteric lymph node (MLN) cells of transgenic mice fed ovalbumin. (a) Interleukin (IL) 2, (b) IL-4, (c) interferon (IFN)- $\gamma$. $\square$, Control; $\mathbb{Z}$, raffinose. Transgenic mice fed a basal diet or raffinose-containing diet for 2 weeks were maintained for a further 1 week whilst being fed their respective diet plus ovalbumin (OVA). CD4 ${ }^{+}$MLN cells prepared from pooled MLN of each group were cultured with antigen-producing cells in the presence of OVA at various concentrations for $36 \mathrm{~h}$ (for IL-2) or $60 \mathrm{~h}$ (for IL-4 and IFN- $\gamma$ ). BALB/c splenocytes treated with mitomycin C were used as antigen-producing cells. Animal experiments were repeated six times. The levels of cytokines in the culture supernatant fractions were determined by ELISA. For details of diet and procedures, see p. 422. Values are means for six independent experiments with standard errors shown by vertical bars. Mean values were significantly different from those of the control group: ${ }^{*} P<0.05$.
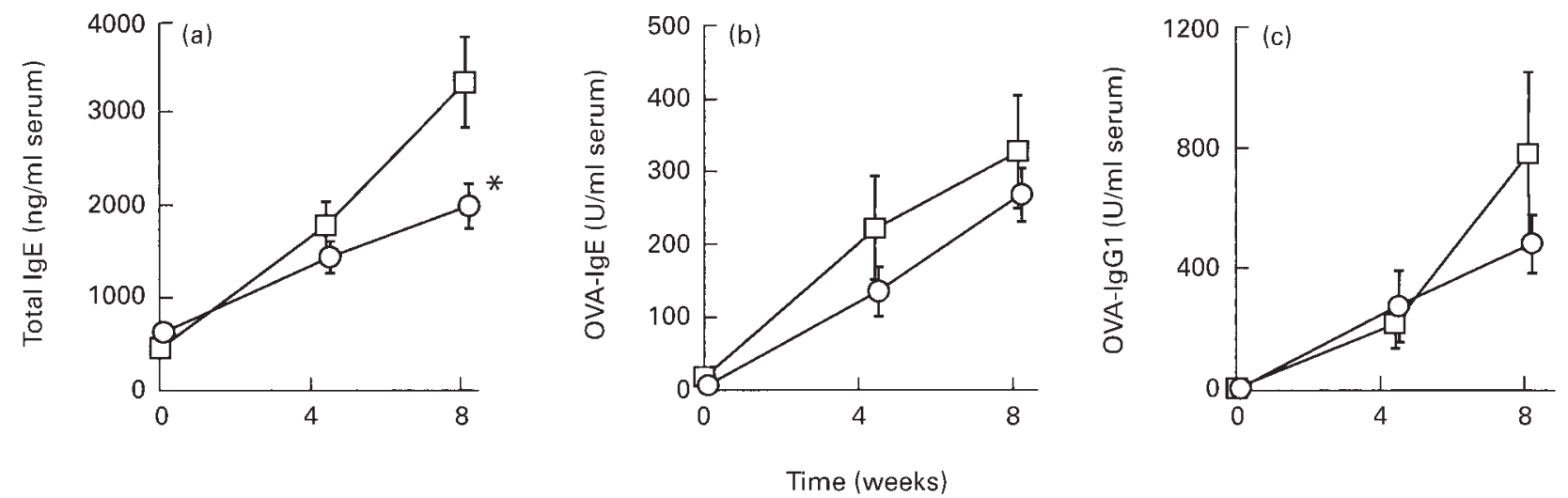

Fig. 3. Effect of feeding raffinose on serum immunoglobulin (Ig) E levels induced by oral ingestion of ovalbumin (OVA). (a) Total IgE, (b) OVA$\operatorname{IgE}$, (c) OVA-IgG1. $\square$, Control; $O$, raffinose. Transgenic mice were fed a basal diet or raffinose-containing diet during the experimental period. Two weeks after the start of feeding experimental diets, the mice were exposed to OVA via drinking water (20 g OVA/I) until the end of the experiment. The levels of antibodies in the serum during the period OVA-containing drinking water was administered (week 0-8) were determined by using ELISA. For details of diet and procedures, see p. 422. Values are means for ten mice with standard errors shown by vertical bars. Mean values were significantly different from those of the control group: ${ }^{*} P<0.05$.

cellular immune responses (Gill et al. 2000) and suppress IgE production through stimulation of IL-12 production (Matsuzaki et al. 1998; Murosaki et al. 1998; Shida et al. 1998). Moreover, oral administration of lactobacilli GG strain has been shown to reduce the symptoms of Th2mediated allergic disease in children at high risk (Kalliomaki et al. 2001). In addition, the recent epidemiological study of the intestinal microflora of allergic and non-allergic children has shown lower frequency of lactobacilli and bifidobacteria and higher counts of aerobes in the allergic children (Bjorksten et al. 1999). The difference in composition of indigenous microflora might also influence the immune system of the host. Dietary raffinose has been shown to induce changes in intestinal microflora (Benno et al. 1987). Thus, it is possible that the suppressive effect of raffinose on Th2 cell-mediated immunity may be caused by a raffinose-altered intestinal microflora. At the least, we observed that adding raffinose to an in vitro culture of PP cells from BALB/c mice did not affect IL12 and IFN- $\gamma$ production (Fig. 1). However, it is necessary to study further the possibility that raffinose directly affects the immune response, as it is known that a small amount of non-digestible oligosaccharide is absorbed in the intestine (Pike et al. 1986), and a digestible oligosaccharide has been reported to have in vitro and in vivo immunopotentiating activity for the Th1-type immune response (Murosaki et al. 1999).

In conclusion, we have found novel effects of the nondigestible oligosaccharide raffinose, which was associated with suppression of $\operatorname{IgE}$ production through suppressing Th2-type immune responses against oral antigen. We will investigate further whether this function of raffinose is caused by the change of intestinal environment, such as microflora, or not. This knowledge may provide a useful approach for prevention and therapy of allergic disease.

\section{Acknowledgements}

We wish to thank Dr M. Totsuka and M. Hibi for their helpful suggestions. 


\section{References}

American Institute of Nutrition (1979) Report of the American Institute of Nutrition ad hoc committee on standards for nutritional studies. Journal of Nutrition 107, 1340-1348.

Benno Y, Endo K, Shiragami N, Sayama K \& Mitsuoka T (1987) Effects of raffinose intake on human fecal microflora. Bifidobacteria and Microflora 6, 59-63.

Berg RD (1983) Host immune response to antigens of the indigenous intestinal flora. In Human Intestinal Microflora in Health and Disease, pp. 101-126 [DJ Hentges, editor]. New York: Academic Press.

Bjorksten B, Naaber P, Sepp E \& Mikelsaar M (1999) The intestinal microflora in allergic Estonian and Swedish 2-year-old children. Clinical and Experimental Allergy 29, 342-346.

Coffman RL, Ohara J, Bond MW, Carty J, Zlontnik A \& Paul WE (1986) B cell stimulatory factor-1 enhances the IgE response of lipopolysaccharide-activated B cells. Journal of Immunology 136, $4538-4541$.

Fitch FW, Mckisic MD, Lancki DW \& Gajewski TF (1993) Differential regulation of murine $\mathrm{T}$ lymphocyte subsets. Annual Review of Immunology 11, 29-48.

Fujisaki H, Nagura T, Kawamoto T \& Sayama K (1994) The effects of raffinose administration on the fecal flora, organic acids and putrefactive products in humans. Bifidus 8, 1-5 (in Japanese).

Gill HS, Rutherfurd KJ, Prasad J \& Gopal PK (2000) Enhancement of natural and acquired immunity by Lactobacillus rhamnosus (HN001), Lactobacillus acidophilus (HN017) and Bifidobacterium lactis (HN019). British Journal of Nutrition 83, 167-176.

Hidaka H, Tashiro Y \& Eida T (1991) Proliferation of Bifidobacteria by oligosaccharides and their useful effect on human health. Bifidobacteria Microflora 10, 65-79.

Kalliomaki M, Salminen S, Arvilommi H, Kero P, Koskinen P \& Isolauri E (2001) Probiotics in primary prevention of atopic disease: a randomized placebo-controlled trial. Lancet $\mathbf{3 5 7}$, 1076-1079.

Matsuda M, Takeuchi S \& Nagura T (1998) Influence of raffinose for atopic dermatitis. Allergy in Practice 18, 1092-1095 (in Japanese).

Matsuzaki T, Yamazaki R, Hashimoto S \& Yokokura T (1998) The effect of oral feeding of Lactobacillus casei strain Shirota on immunoglobulin E production in mice. Journal of Dairy Science 81, 48-53.

Murosaki S, Yamamoto Y, Ito K, Inokuchi T, Kusaka H, Ikeda H \& Yoshikai Y (1998) Heat-killed Lactobacillus plantarum L137 suppresses naturally fed antigen-specific IgE production by stimulation of IL-12 production in mice. Journal of Allergy and Clinical Immunology 102, 57-64.

Murosaki S, Muroyama K, Yamamoto Y, Kusaka H, Liu T \& Yoshikai Y (1999) Immunopotentiating activity of nigerooligosaccharides for the T-helper1-like immune response in mice. Bioscience Biotechnology and Biochemistry 63, 373-378.
Nagura T, Muraguchi H, Uchino K, Aritsuka T \& Benno Y (1999) Effects of ingestion of raffinose-rich soup on the fecal flora and daily defecation in humans. Journal of Intestinal Microbiology 13, 1-7 (in Japanese).

O'Garra A (1998) Cytokines induce the development of functionally heterogeneous T-helper cell subsets. Immunity 8, 275-283.

Pike MG, Heddle RJ, Boulton P, Turner MW \& Atherton DJ (1986) Increased intestinal permeability in atopic eczema. Journal of Investigative Dermatology 86, 101-104.

Rathbone EB (1980) Raffinose and melezitose. In Developments in Food Carbohydrate - 2, pp. 146-149 [CK Lee, editor]. London: Applied Science Publisher Ltd.

Sako T, Matsumoto K \& Tanaka R (1999) Recent progress on research and applications of non-digestible galacto-oligosaccharides. International Dairy Journal 9, 69-80.

Sato T, Sasahara T, Nakamura Y, Osaki T, Hasegawa T, Tadakura T, Arata Y, Kumagai Y, Katsuki M \& Habu S (1994) Naïve T cell can mediate delayed-type hypersensitivity response in $\mathrm{T}$ cell receptor transgenic mice. European Journal of Immunology 24, $1512-1516$

Sayama K, Kamada T, Oikawa S \& Masuda T (1992) Production of raffinose: A new byproduct of the beet sugar industry. Zuckerindustry 117, 893-898.

Sher A \& Coffman RL (1992) Regulation of immunity to parasites by $\mathrm{T}$ cells and T cells-derived cytokines. Annual Review of Immunology 10, 385-409.

Shida K, Makino K, Morishita A, Takamizawa K, Hachimura S, Ametani A, Sato T, Kumagai Y, Habu S \& Kaminogawa $S$ (1998) Lactobacillus casei inhibits antigen-induced $\operatorname{IgE}$ secretion through regulation of cytokine production in murine splenocytes cultures. International Archives of Allergy and Immunology 115, 278-287.

Shida K, Hachimura S, Ametani A, Ishimori M, Ling M, Hashiguchi M, Ueda Y, Sato T, Kumagai Y, Takamizawa K, Habu S \& Kaminogawa S (2000) Serum IgE response to orally ingested antigen: A novel IgE response model with allergen-specific T-cell receptor transgenic mice. Journal of Allergy and Clinical Immunology 105, 788-795.

Sudo N, Sawamura S, Tanaka K, Aiba Y, Kudo C \& Koga Y (1997) The requirement of intestinal bacterial flora for the development of an $\mathrm{IgE}$ production system fully susceptible to oral tolerance induction. Journal of Immunology 159, 1739-1745.

Van Loo J, Cummings J, Delzenne N, Englyst H, Franck A, Hopkins M, Kok N, Macfarlane G, Newton D, Quigley M, Roberfroid M, van Vliet T \& van den Heuvel E (1999) Functional food properties of non-digestible oligosaccharides: a consensus report from the ENDO project (DGXII AIRIICT94-1095). British Journal of Nutrition 81, 121-132.

Yamamoto M, Rennert P, McGhee JR, Kweon M, Yamamoto S, Dohi T, Otake S, Bluethmann H, Fujihashi K \& Kiyono H (2000) Alternate mucosal immune system: organized Peyer's patches are not required for $\operatorname{IgA}$ responses in the gastrointestinal tract. Journal of Immunology 164, 5184-5191. 